\title{
Molecular systematics of the armored neotropical catfish subfamily Neoplecostominae (Siluriformes: Loricariidae)
}

\author{
FÁBIO F. ROXO ${ }^{1,3}$, CLÁUDIO H. ZAWADZKI², GUILHERME J. DA COSTA SILVA', \\ MARCIO C. CHIACHIO ${ }^{1}$, FAUSTO FORESTI ${ }^{1} \&$ CLAUDIO OLIVEIRA ${ }^{1}$ \\ ${ }^{1}$ Universidade Estadual Paulista, UNESP, Departamento de Morfologia, Laboratório de Biologia e Genética de Peixes, Botucatu, SP, \\ Brazil \\ ${ }^{2}$ Universidade Estadual de Maringá, UEM, Nupélia, Maringá, PR, Brazil \\ ${ }^{3}$ Corresponding author.E-mail: roxoff@ hotmail.com.br
}

\begin{abstract}
Morphological and molecular studies in the family Loricariidae have revealed that the relationships among its members are not yet well resolved, and the present study was conducted with the main objective of improving our knowledge about this highly diversified group of catfishes. Maximum parsimony and Bayesian analysis were conducted on a matrix of 53 terminal taxa and 4676 characters with partial sequences of the genes COI, CytB, 16S rRNA, 12S rRNA and F-reticulon 4. As outgroups, samples of the species Hemipsilichthys gobio and H. papillatus (subfamily Delturinae), Rineloricaria jaraguensis (subfamily Loricariinae), Hypostomus nigromaculatus (subfamily Hypostominae), Hypoptopoma inexpectatum (subfamily Hypoptopomatinae), and Corumbataia cuestae (subfamily Otothyrinae) were used. The results showed that the subfamily Neoplecostominae is monophyletic, including Pseudotocinclus, and three clades were recognized. The first one is composed of Pareiorhina rudolphi, P. cf. rudolphi and Pseudotocinclus. The second is composed of Isbrueckerichthys, Pareiorhaphis, Kronichthys and Neoplecostomus ribeirensis. The third is composed of the remaining species of the genera Neoplecostomus, except $N$. ribeirensis, Pareiorhina carrancas, P. cf. carrancas, Pareiorhina sp. 1 (possible new species) and an undescribed taxon referred to in this paper as new genus and species 2. In our analyses, Pareiorhina and Neoplecostomus are paraphyletic taxa.
\end{abstract}

Key words: freshwater, Loricariidae, mitochondrial DNA, nuclear gene, phylogenetic analysis

\section{Introduction}

Loricariidae, an armored catfish family with 973 species currently recognized (Eschmeyer 2011), is the largest Neotropical endemic freshwater fish family. Loricariid revisionary studies began with Eigenmann and Eigenmann (1890), who divided the family into three subfamilies (Loricariinae, Hypoptopominae, and Plecostominae). Thereafter, Regan (1904), in a broad analysis of Loricariidae, divided the family in five subfamilies (Plecostominae, Hypoptopomatinae, Loricariinae, Arginae, and Neoplecostominae). In that study, Regan named the subfamily Neoplecostominae to include Neoplecostomus granosus and suggested that this group was closely related to Astroblepus (of the subfamily Arginae), representing an intermediate form between the armored and the naked catfish species. Gosline (1947) was the first to propose an expanded Neoplecostominae including Corymbophanes, Delturus, Hemipsilichthys, Kronichthys, Neoplecostomus, Pareiorhaphis, Pareiorhina, Pogonopoma, Pogonopomoides, Canthopomus (=Pseudorhinelepis), Rhinelepis, and Upsilodus. Isbrücker (1980) also separated Loricariidae into five subfamilies (Loricariinae, Hypoptopomatinae, Neoplecostominae, Hypostominae and Ancistrinae) and again considered Neoplecostomus as the single genus in Neoplecostominae.

Howes (1983) was the first author to perform a cladistic analysis of osteological and myological data of the Loricariidae and found that the family had six monophyletic groups (Loricariinae, Hypoptopomatinae, Hypostominae, Neoplecostominae, Lithogeninae, and Chaetostominae). Schaefer (1987), after a cladistic analysis, also recognized six subfamilies in Loricariidae (Lithogeneinae, Neoplecostominae, Hypoptopomatinae, Loricariinae, 